\section{INFLUENCE OF MOTION PARAMETERS OF THE DRYING AGENT ON KINETICS OF MIXED HEAT TRANSFER DRYING (p. 4-8)}

Micola Pogozhikh, Andrey Pak, Alina Pak, Maxim Zherebkin

The paper deals with studying the influence of motion parameters of the drying agent on the kinetics of mixed heat transfer drying for obtaining the requirements to functional features of turbulators, used in drying by this method.

It was noted that one of the promising drying methods in terms of increasing the dehydration intensity, reducing specific energy consumption per unit of dried products and preserving the feedstock quality is mixed heat transfer drying.

Installation for studying the influence of motion parameters of the drying agent on the temperature kinetics and the moisture content kinetics of feedstock during MHT-drying was designed and built. Based on studies of temperature kinetics and moisture content kinetics of feedstock at different angles of blowing of mass transfer gaps by drying agent from the range $0^{\circ}-90^{\circ}$ it was found that the temperature kinetics of feedstock at the investigated blowing angles are of nature, typical for the MHT-process. It was determined that the dehydration duration is the longest for blowing angles $25^{\circ}-35^{\circ}$, time the thermogram achieves local minimum and, respectively, maximum of drying speed for this range is the latest. It was found that at increasing and decreasing the blowing angle with respect to this range, drying duration reduces and maximum dehydration speed is reached earlier. It is noted that inserts-turbulators, which are structural features of MHTdryers, must provide blowing of FC mass transfer gaps by drying agent at angles, close to rational, which are the angles $0^{\circ}$ and $60^{\circ}$.

Keywords: mixed heat transfer drying, functional capacity, temperature kinetics, turbulent disturbances, blowing.

\section{References}

1. Hooshmand, S., Arjmandi, H. (2009). Viewpoint: Dried plum, an emerging functional food that my effectively improve bone health. Ageing Res Reviews, 8, 122-127.

2. Hui, Yh. (2006) Handbook of fruits and fruit processing. Blackwell Publishing, Oxford UK, 81.

3. Vinson, Ja., Zubic, L., Bose, P. (2005). Dried fruits: excellent in vivo and in vitro antioxidants. J Amer Coll Nutr, 24, 44-50.

4. Scanlin, D. (1997). The Design, Construction and Use of an Indirect, Through-Pass, Solar Food Dryer. Home Power magazine, 57, $62-72$.

5. Wilson, T., Luebke, E. F., Carrell, M. C., Leveranz, L. K., Schmidt, T. P., Limburg, P. J., Vorsa, N., Singh, A. P. (2010). Glycemic Responses to Sweetened Dried and Raw Cranberries in Humans with Type 2 Diabetes. Journal of Food Science, Vol. 75 (8), 218-223.

6. DeLong, D. (1992). Cherries: How to dry foods. HPBooks, 29.

7. Barrett, D. M., Somogyi, L. P., Ramaswamy, H. S. (2004). Dehydrated cherries, Processing Fruits: Science and Technology, CRC Press, 506-507.

8. Yu, L., Mazza, G., Jayas, D. S. (1999). Moisture sorption characteristics of freeze-dried, osmofreeze-dried, and osmo-air-dried cherries and blueberries. Transactions of the American Society of Agricultural Engineers, 42 (1), 141-147.

9. Esmaiili, M., Sotudeh-Gharebagh, R., Cronin, K., Mousavi, M. A. E., Rezazadeh, G. (2007). Grape Drying: A Review. Food Reviews International, 23 (3), 257.

10. Pogozhikh, N. I. (2002). Nauchnie osnovi teorii i techniki sushki pishchevogo sirya v massoobmennih modulyah. Kharkiv : KSUFT, 331.

11. Tsurkan, N. M. (2000). Razrabotka ratsionalnih rezhimov proizvodstva sushonogo bistrovosstanavlivaemogo kartofela. Kharkiv : KSUFT, 156

12. Pak, A. O. (2008). Rozrobka protsesu sushinna plodovo-yagidnoi siroviny zi shtuchnim poroutvorennam. Kharkiv : KSUFT, 153

13. Zherebkin, M. V. (2013). Rozrobka protsesu gidrotermichnoi obrobki krup z vikoristannam principiv sushinna zmishanym teplopidvodom. Kharkiv : KSUFT, 151.
14. Bradshaw, P. (1974). An introduction no turbulence and its measurement. M.: «Mir», 278.

15. Rockwell, D. (1998). Vortex-body interactions. Ann. Rev. Fluid Mech, 30, 199-229.

\section{MODELING OF THE PROTEOLYSIS PROCESS OF \\ FISH COLLAGEN RAW MATERIALS (p. 8-13)}

Nina Dudenko, Alexandr Dyakov, Bogdana Panikarova

The studies aimed at modeling the process of fish collagen raw material proteolysis by using enzyme preparations of collagenase and bromelin are given in the paper. The data for determining reasonable ranges of the proteolysis parameters, in particular, the temperature and duration of the proteolysis, $\mathrm{pH}$ and concentration of enzyme preparations, are given. The obtained set of data indicates the high efficiency of collagenase in relation to connective-tissue proteins. The mathematical model of the process of fish collagen raw materials proteolysis was developed and significant technological factors that provide functional and technological properties of the final product were determined. The proteolysis parameters, namely duration of (9...11) $\times 60 \mathrm{~s}$, temperature of $40 \pm 2{ }^{\circ} \mathrm{C}$, type and concentration of the enzyme preparation $\mathrm{C}_{\text {collagenase }}=0,050 \pm 0,005 \%$ to the mass of fish raw materials, value of the $\mathrm{pH}$ medium $7,0 \pm 0,2$ were scientifically justified. The obtained results can be used for solving the problems of control and management of the process of the fish collagen proteolysis and controlled accumulation of water-soluble fractions of connective tissue of the salmon skin, depending on the composition and type of the raw materials.

Keywords: fish collagen raw materials, proteolysis, protein supplement, collagenase, bromelin, mathematical modeling.

\section{References}

1. Petrova, I. B., Klimenko, A. I. (2012). Kompleksnaja pererabotka othodov rybopererabatyvajushhih proizvodstv: obzor. Molodoj uchenyj, 9, 61-63.

2. Rustad, T. O. (2003). Utilisation of marine by-products. Electronic Journal of Environmental, Agricultural and Food Chemistry, 2, 458-463.

3. Nalinanon, S., Benjakul, S., Kishimura, H. (2010). Collagen from the skin of arabesque greenling (pleurogrammus azonus) solubilized with the aid of acetic acid and pepsin from albacore tuna (thunnus alalunga) stomach. Journal of the Science of food and Agriculture, Vol. 90, № 9, 1492-1500.

4. Antipova, L. V., Dvorjaninova, O. P. (2002). Ocenka perspektiv primenenija vtorichnyh resursov rybopererabatyvajushhej promyshlennosti na osnove mikrostrukturnoj harakteristiki. Netradicionnye prirodnye resursy, innovacionnye tehnologii i produkty. RAENMAANOI, Vol. 6, 83-94.

5. Cibizova, M. E., Razumovskaja, R. G., Kao, Thi Hue, Pavlova, G. A. (2011). Prakticheskie aspekty poluchenija strukturoobrazovatelej iz kollagensoderzhashhego rybnogo syr'ja. Vestnik Astrahanskogo gosudarstvennogo tehnicheskogo universiteta. Serija: Rybnoe hozjajstvo, 1, 145-151.

6. Krashhenko, V. V., Panchishina, E. M., Beloborod'ko, A. V. (2011). Issledovanie vlijanija chastichnoj fermentativnoj obrabotki pishhevyh othodov lososevyh na kachestvo rybnyh bul'onov. Dal'rybvtuza, Vol. 23, 165-169.

7. Chudinova, L. L., Antipova, L. V., Dvorjaninova, O. P., Grebenshhikov, A. V. (2009). Perspektivy ispol'zovanija verhnih pokrovov presnovodnyh ryb. Rybprom, 4, 28-32.

8. Takeshi, N., Masamil, I., Masahide, I. (2004). Fish scale collagen. Preparation and partial characterization. International Journal of Food Sciense \& Technology, Vol. 39, № 3, 239244.

9. Nalinanon, S., Benjakul, S., Kishimura, H., Osako, K. (2011). Type I collagen from the skin of ornate threadfin bream (nemipterus hexodon): characteristics and effect of pepsin hydrolysis. Food chemistry, 2, 500-507.

10. Takeshi, N., Keiko, N., Eiji, Y., Nobutaka, S. (2002). Collagen of octopus callistoctopus arakawai arm. International Journal of Food Sciense \& Technology, Vol. 37, № 3, 285-289. 
11. Rumshinskaja, L. Z. (1971). Matematicheskaja obrabotka rezul'tatov jekspe-rimenta. Nauka, 192.

12. Zhvanko, Ju. N., Snegireva, I. A. (1976). Sovremennye metody issledovanija kachestva pishhevyh produktov. Jekonomika, 222

13. Gracheva, I. M., Krivova, A. Ju. (2000). Tehnologija fermentnyh preparatov. Jelevar, 256

14. Kosenko, I. S. (2009). Primenenie fermentnyh preparatov proteoliticheskogo dejstvija v obrabotke kollagensoderzhashhih produktov uboja zhivotnyh. Voronezh, 252 .

\section{EFFECT OF HOT TREATMENT BY ANTIOXIDANTS ON THE SHELF LIFE AND QUALITY OF SWEET PEPPER (p. 14-18)}

\section{Olesia Priss, Valentina Kalitka}

In order to prolong shelf life of sweet pepper and maintain its high quality heat treatment solution by integrated antioxidant is proposed in the article.

This treatment involves dipping the fruit in a solution of antioxidant complex with ionol, lecithin and horseradish root extract at a temperature of $45^{\circ} \mathrm{C}$ for $15 \mathrm{~min}$. The use of this treatment allows to extend the duration of pepper fruits storage for 2 weeks. The level of chilling injury can be reduced in 7 ... 9 times, the chilling severity can be reduced in 9 ... 12 times. An average weight loss per day during treatment is reduced almost twice, the rate of decline of dynamic firmness is reduced in 1.4 times. All this contributes to the increasing of the commodity products output of, which makes up $88 \%$ with taking into account weight loss after storage for 30 days.

Keywords: storage, postharvest treatment, antioxidants, sweet peppers, chilling injury.

\section{References}

1. Sikora, E., Cieslik, E., Topolska, K. (2008). The sources of natural antioxidants. Acta Sci. Pol., Technol. Aliment., 7(1), 5-17.

2. Marín, A., Ferreres, F., Tomás-Barberán, F. A., Gil, M. (2004). Characterization and quantitation of antioxidant constituents of sweet pepper (Capsicum annuum L.). J. Agric. Food Chem., 52, 3861-3869.

3. Kouassi, C. K., Koffi-Nevry, R., Guillaume, L. Y., Yéssé, Z. N., Koussémon, M., Kablan, T., Athanase, K. K. (2012). Profiles of bioactive compounds of some pepper fruit (Capsicum L.) varieties grown in Côte D'ivoire. Innovat. Rom. Food Biotechnol., 11, 23-31.

4. Deepa, N., Kaur, C., George, B., Singh, B., Kapoor, H. C. (2007). Antioxidant constituents in some sweet pepper (Capsicum annuum L.) genotypes during maturity. LWT-Food Sci. Technol., 40, 121-129.

5. Guil-Guerrero, J. L., Martínez-Guirado, C., del Mar RebollosoFuentes, M., Carrique-Pérez, A. (2006). Nutrient composition and antioxidant activity of 10 pepper (Capsicum annuun) varieties. European Food Research and Technology, 224, 1-9.

6. Kwon, Y. I., Apostolidis, E., Shetty, K. (2007). Evaluation of pepper (capsicum annuum) for management of diabetes and hypertension. Journal of Food Biochemistry, 31, 370-385.

7. Small, D. M., Gobe, G. C. (2013). Oxidative stress and antioxidant therapy in chronic kidney and cardiovascular disease. Oxidative stress and chronic degenerative diseases - a role for antioxidants, InTech, 233-264.

8. Valadez-Vega, C., Delgado-Olivares, L., Morales González, J. A., Alanís García, E., Villagomez Ibarra, J. R., Ramírez Moreno, E., Sánchez Gutiérrez, M., Sumaya Martínez, M. T., Zuñiga Pérez, C., Calderón Ramos, Z. (2013). The role of natural antioxidants in cancer disease. Oxidative stress and chronic degenerative diseases - a role for antioxidants, InTech, 391-418.

9. Jadhav Sameer, S., Salunkhe Vijay, R., Chandrakant, M. S. (2013). Daily consumption of antioxidants: - prevention of disease is better than cure. Asian J. Pharm. Res. 3, 34-40.

10. Nyanjage, M. O., Nyalala, S. P. O., Illa, A. O., Mugo, B. W., Limbe, A. E., Vulimu, E. M. (2005). Extending post-harvest life of sweet pepper (Capsicum annum L. 'California Wonder') with modified atmosphere packaging and storage temperature. Agricultura Tropica et Subtropica, 38, 28-32.

11. Ochoa-Reyes, E., Martínez-Vazquez, G., Saucedo-Pompa, S., Montañez,J., Rojas-Molina, R., de Leon-Zapata, M.A., Rodríguez-Herrera, R., Aguilar, C. N. (2013). Improvement of shelf life quality of green bell peppers using edible coating formulations. Journal of Microbiology, Biotechnology and Food Sciences, 2, 2448-2451.

12. Wismer, W. V. (2003). Low temperature as a causative agent of oxidative stress in postharvest crop. Postharvest oxidative stress in horticultural crops, Food Products Press, 55-68.
13. Gonzales-Aguilar, G. A. (2007). The commercial storage of fruits, vegetables and florist and nursery stocks. Agr. Hdbk. No. 66, US Dept.Agr., Washington, DC. Available at: <http://www.ba.ars.usda. gov/hb66/contents.html>.

14. Lim, C. S., Kang, S. M., Cho, J. L., Gross, K. C., Woolf, A. B. (2007) Bell pepper (Capsicum annuum L.) fruits are susceptible to chilling injury at the breaker stage of ripening. HortScience, 42, 1659-1664.

15. Fallik, E., Bar-Yosef, A., Alkalai-Tuvia, S., Aharon, Z., Perzelan, Y., Ilić, Z., Lurie, S. (2009). Prevention of chilling injury in sweet bell pepper stored at $1.5{ }^{\circ} \mathrm{C}$ by heat treatments and individual shrink packaging. Folia Horticulturae, 21, 87-97.

16. Wang, C. Y. (2010). Alleviation of chilling injury in tropical and subtropical fruits. Acta Hort., 864, 267-273.

17. Purvis, A. C. (2002). Diphenylamine reduces chilling injury of green bell pepper fruit. Postharvest Biology and Technology, 25, 41-48.

18. Priss, O. P., Prokudina, T. F., Zhukova, V. F. (2011). Antioxidant composition for the treatment of fruit vegetables before storage Pat. 59733 Ukraine, IPC A 23 7/14.

19. Gorodnii, N. M., Gorodniaia, M. Y., Volkodav, V. V., Matasar, I. T., Bykin, A. V., Oliinichenko, V. G., Gonchar, A. N., Chaika, V. D (2002). Fruit and vegetable resources and their medical and biological evaluation. Kyiv, LLC "Alepha”, 447.

20. Smith, D. L., Stommel, J. R., Fung, R. W. M., Wang, C. Y., Whitaker, B. D. (2006). Influence of cultivar and harvest method on postharvest storage quality of pepper (Capsicum annuum L.) fruit. Postharvest Biology and Technology, 42, 243-247.

21. Kan, E. E. L., Sargent, S. A., Simonne, A., Shaw, N. L., Cantliffe, D. J (2007). Changes in the postharvest quality of datil hot peppers as affected by storage temperature. Proceedings - Florida State Horticultural Society, 120, 246-250.

\section{SENSORY ANALYSIS OF BIOFORTIFIED PICKLED PEPPERS (p. 18-24)}

Gregoriy Deynichenko, Olha Yudicheva

A sensory analysis of biofortified pickled peppers, obtained by traditional production technology and technology, which provides additional use of ginger root in the spice rack is conducted. Peppers for processing are grown using eco-friendly fertilizer "Riverm", which provides a natural increase in the content of vitamins and minerals in vegetables (agronomic biofortification).

Applying biofortification when growing vegetables is one of the ways to increase the content of important for people minerals and vitamins, which in turn affects the balance of the diet.

But today the impact of biofortification on the sensory properties of the obtained crop products remains uninvestigated. Also, there is no information about the possibilities of using biofortified vegetables for processing, as well as change in sensory parameters of finished products depending on the production technology.

Modern analytical estimation methods - categorization method (gradation by quality) and quantitative descriptive (profile) method were used during the study. The results have proved that pickling as a way of processing biofortified peppers is appropriate. Using ginger root in pickling improves the finished product quality, in particular flavor and aroma. Profile taste analysis of biofortified pickled peppers has led to the conclusion that the sample, produced with adding the ginger root in the spice rack, was characterized by a pleasant, spicy and harmonious flavor. The aroma of pickled biofortified peppers, produced with using the spice rack with the added ginger root, was spicy, harmonious, very enjoyable and impressed tasters more than that of the control sample.

Thus, biofortified peppers can be used for pickling processing using different spice racks. Agricultural producers of biofortified vegetables can plan pickling for their processing, which is able to give high sensory properties to finished product.

Keywords: pickling, sensory analysis, descriptors, biofortification, pepper, fertilizer "Riverm", ginger, method.

\section{References}

1. Kantere, V. M. (2003). Sensornyi analiz productov pitaniya. Moscow, Russia: Typographiya RASHN, 400.

2. Mikroelementy-makroposledstviya (2014). Available at: www.nffp. uz/rus/problems/microelements/.

3. Vitamin B9 (foliievaia kislota) (2014). Calorizator. Available at: http://www.calorizator.ru/vitamin/b9/. 
4. Postanova Prezydii Natsionalnoi akademii nauk vid 8chervnia 2011 roku № 189 «Pro shvalennia proectu Kontseptsii Derzhavnoi naukovo-tehnichnoi program «Biofortuficatsiia ta funktsionalni product na osnovi roslynnoi syrovyny na 2012-2016 roky» (2014). Zakon I normatyv. Available at : http://www.licasoft.com.ua/component/lic a $/$ href $=0$ \&view $=$ text \&base $=1 \&$ id $=647009 \&$ menu $=807115 /$.

5. World Declaration on Nutrition (2014). FAO Corporate Document Repository. Available at: http://www.fao.org/docrep/u9920t/ u9920t0a.htm/.

6. International Conference on Nutrition, Rome (2014). Available at: http: //www.unostamps.nl/subject_international_conference_nutrition.htm//.

7. Biotechnology and Biofortification (2014). ISAAA. Available at: http:// www.isaaa.org/resources/publications/pocketk/27/default.asp/.

8. Biofortification of rice. Available at: <http://www.slideshare.net/ eugenetafadzwamadzokere/biofortification-of-rice $>$.

9. Udintsev, S. N. (2014). Samyi glavnyi product. Available at : http:// www.sibniit.tomsknet.ru/index.php?option $=$ com_content\&task $=$ vi ew\&id=158\&Itemid $=62 /$

10. Cakmak, I. (2008). Enrichment of Cereal Grains with Zinc: Agronomic or Genetic Biofortification. Plant Soil, 302, 1-17.

11. Philip, J. White1, Martin R. Broadley (2009). Biofortification of crops with seven mineral elements often lacking in human diets iron, zinc, copper, calcium, magnesium, selenium and iodine. New Phytologist, April, 49-84.

12. Kozak, V. V. (2009). Printsipy ekologicheski bezopasnogo zemledeliya. Kiev, Ukraine: MEF «AQUA-VITAE», 38.

13. Deinychenko, H. V., Yudicheva, O. P. (2012). Vykorystannia tradytsii biofortyfikatsii ta regul'uvannia himichnogo skladu tomatnyh ovochiv. Harchova nauka i tehnologiia, 2 (19), 42-45.

14. Zhuk, V. A. (1999). Sensornyi analiz: Navchal'nyi posibnyk dlia studentiv vushchyh navchal'nyh zakladiv. Kiev, Ukraine: «Ukooposvita», 231.

15. Barylko-Pikielna, N., Golembiowski, T. (1966). Zarys analizy sensorycznej. Krakow, Poland: WSE, 98-213.

16. Barvil, J., Pokorny, J. (1980). Metody sensorycznej analizy ve vyzkumu, vyvoji a praxi. Prum. Potravin, 11, 659-661.

\section{NEW POSSIBILITIES OF PROCESSING OF ESSENTIAL OILS FOR FOOD AROMATISATION (p. 24-29)}

\section{Natalia Frolova, Olena Usatiuk}

The paper gives new possibilities of processing essential oils, which ensure obtaining individual aromatic substances of high purity, establishing their organoleptic, physicochemical properties and physiological effect on the human body. The sequential combination of three stages of processing: vacuum rectification, preparative extraction and gas chromatographic control of content purity of the obtained products, was proposed for the first time. The conditions for the separation and extraction of components of essential oils were optimized. The technique of analytical gas-solid chromatography on an optically active stationary phase to control the purity of the extracted substances was developed. The obtained aromatic products, namely the individual components of essential oils and "narrow" vacuum rectification fractions, relate to natural flavors, which are in short supply in the domestic market today. The research results will promote the development of domestic technologies of food flavors, are of considerable attractiveness for food, perfume and cosmetics, pharmaceutical and other industries.

Keywords: essential oils, aromatics, "narrow" fraction, vacuum rectification, natural flavors.

\section{References}

1. Smirnov, E. V. (2011). Flavourings: History and Modernity. Food Industry, 5, 60-63.

2. Smirnov, E. V. (2008). Food flavourings. Handbook, St. Petersburg, Profession, 736

3. Tkachenko, K. H. (2011). Essential oils plants and essential oils: achievements and perspectives, current trends of study and application. Bulletin of Udmurt University, 1, 88-100.

4. Frolova, N. E. (2010). Processing of essential oils to produce natural food flavourings. Science and Innovation, 2, 36-40.

5. Tkachev, A. B. Investigation of plant volatile substances, Novosibirsk, Offset, 969.
6. Maurice, C. R. (2005). Franssen. Biocatalytic production of flavors and fragrances. Pure Appl. Chem., 1, 273-279.

7. Panda, H. (2010). Perfumes and Flavours Technology Handbook, Delhi, Asia Pacific Business Press Inc., 704.

8. Andrew J. Taylor. (2010). Food Flavour Technology, New Jersay: Wiley-Blackwell, 351.

9. Ziegler, H. (2007). Flavourings. Production, composition, application, regulation. Second edition. Berlin, Wiley-VCH, 811.

10. AS № 2133767, Russian Federation, MKP7 C11 B 9/00. Method of processing of fennel essential oil by rectification. № 5429704; appl. 16.11.1999; publ. 03.09. 2000, Bul. №2.

\section{INCREASING OF MICROBIOLOGICAL STABILITY OF BAKERY PRODUCTS WITH USING PLASMA- CHEMICAL TECHOLOGIES (p. 30-36)}

Svitlana Mykolenko, Olexander Pivovarov, Anna Tischenko

Solving the problem of preventing spoilage of food products is one of the most important tasks of the food industry. Bakery products refer to the segment of food products with a high demand in the market, therefore, the question of their safety is extremely important. Synthetic additives, the presence of which can adversely affect human health are often used to extend the shelf life of bakery goods. Using water pretreatment by contact nonequilibrium lowtemperature plasma is an innovative approach to the raw materials preparation at the initial production stage of bakery goods. The results of studying the effect of plasma-chemically activated water on the change of consumer properties of bakery products, related to their microbial spoilage during storage are given in the paper. It is shown that using water, additionally treated by contact nonequilibrium plasma prevents molding of a wide variety of products that allows to extend their shelf life. Applying plasma-chemically activated water adversely affects the development of the spores of bacteria, which cause the potato disease of bread. An increase in the microbiological stability of products is demonstrated by a significant reduction in the amount of mesophilic-aerobic and facultative-anaerobic microorganisms and mold fungi in the products, manufactured under the proposed technology. Using the water, exposed to the contact nonequilibrium plasma ensures the manufacture of high-quality storage-stable bakery products that in turn allows to solve the problems of manufacturing ecologically pure food products and the world food problem.

Keywords: bakery products, plasma-chemically activated water, microscopic mold fungi, potato bacillus.

\section{References}

1. Blackburn, C. De W. (2006). Food Spoilage Microorganisms, Cambridge, England, Woodhead Publishing Limited, 736.

2. Bogatyreva, T. G., Sidorova, O. A. (1994). Puti povyshenija mikrobiologicheskoj chistoty hlebobulochnyh i makaronnyh izdelij, metody kontrolja, Moscow, CNIITJIhleboproduktov, 40.

3. Verbina, N. M., Kaptereva, Ju. V. (1988). Mikrobiologija pishhevyh proizvodstv, Moscow, Agropromizdat, 255.

4. Reiß, J. (1981). Studies on the ability of mycotoxins to diffuse in bread, Applied Microbiology and Biotechnology, 12 (4), 239-241.

5. Bogatyreva, T. G., Polandova, R. D., Poljakova, S. P., Ataev, A. A. (1999). Sposoby i sredstva predotvrashhenija plesnevenija hleba, Hlebopechenie Rossii, 3, 16.

6. Poljakova, S. P. (2002). Povyshenie mikrobiologicheskoj ustojchivosti hlebobulochnyh izdelij pri hranenii, Thesis for the Degree of Philosophy Doctor in specialty 05.18.01 Tehnologija obrabotki, hranenija i pererabotki zlakovyh, bobovyh kul'tur, krupjanyh produktov, plodoovoshhnoj produkcii i vinogradarstva, Moscow SSIIBP, 22.

7. Cauvain, P. Stanley, Linda S. Young (2000). Bakery Food Manufacture and Quality: Water Control and Effects, Oxford, Blackwell Publishing Ltd., 209.

8. Kvetnyj, F. M., Sharova T. V., Kushnareva N. K. (1999). Primenenie konservantov v hlebopechenii, Hlebopechenie Rossii, 3, 21.

9. Poljakova, S. P., Bogatyreva, T. G. (2003). Ispol'zovanie ul'trafioletovogo izluchenija dlja bor'by s «kartofel'noj bolezn'ju» hleba, Hlebopechenie Rossii, 5, 28-29.

10. Polandova, R. D., Bogatyreva, T. G., Ataev, A. A. (1998). Kartofel'naja bolezn' hleba: problemy i sovremennye sposoby preduprezhdenija, Hlebopechenie Rossii, 4, 13-14. 
11. Kolupaeva, T. G., Matveeva, I. V., Golovko, T. S. (2001). Vlijanie upakovki na razvitie «kartofel'noj bolezni» hleba, Hlebopechenie Rossii, 6, 10-11.

12. Bykovchenko, T. V. (2009). Zhidkie drozhzhi - jeffektivnoe sredstvo predotvrashhenija «kartofel'noj bolezni» hleba, Hlebopechenie Rossii, $1,14-15$.

13. Smyrnov, V., Sorokulova, I. (2000). Selektyn proty kartoplianoi khvoroby khliba, Zerno i khlib, 1, 24

14. Volohova, T. P., Shestakov, S. K. (1999). Ul'trazvukovaja obrabotka zerna i vody i ee vlijanie na hlebopekarnye svojstva pshenichnoj muki, Hleboprodukty, 10, 22-24.

15. Mazur, P. Ja., Jansheva, I. N., Vystavkin, A. A. (2000). Voda v prigotovlenii hleba, Hlebopechenie Rossii, 6, 30-32.

16. Simakova, O. O. (2009). Vplyv zbahachenoi kaliiem vody na protses tistovedennia, Protsesy ta obladnannia kharchovykh vyrobnytstv: tematychnyj zbirnyk naukovykh prats' DonNUET im. M. TuhanBaranovs'koho, Iss. 20, 272-275.

17. Omelchenko, A., Pivovarov, A. A., Swindall, W. J. (2005). Modern tools and methods of water treatment for improving living standards, Dordrecht, Springer, XVI, 334

18. Kremenchuckij, G. N., Jurgel', L. G., Pivovarov, A. A., Tishhenko, A. P. (2004). Issledovanie dezinficirujushhih svojstv zhidkih sred, obrabotannyh kontaktnoj neravnovesnoj plazmoj, Vestnik Vinnickogo nacional'nogo medicinskogo universiteta, 8 (2), 428-430.

19. Pivovarov, O. A., Mykolenko, S. Yu., Tyschenko, H. P. (2012). Matematychne modeliuvannia ta optymizatsiia tekhnolohichnykh parametriv vyrobnytstva khliba z vykorystanniam plazmokhimichno aktyvovanykh rozchyniv, Visnyk Dnipropetrovs'koho derzhavnoho ahrarnoho universytetu, 2, 51-54.

20. Drobot, V. I., Arsen'ieva, L. Yu., Bilyk, O. A., ed. by Drobot V. I. (2006). Laboratornyj praktykum z tekhnolohii khlibopekars'koho ta makaronnoho vyrobnytstv, Kyiv, Tsentr navchal'noi literatury, 341.

21. Pivovarov, O. A., Mykolenko, S. Yu., Myroshnychenko, L. Yu. (2012). Analiz stanu volohy v khlibi na osnovi plazmokhimichno aktyvovanykh vodnykh rozchyniv, Prohrama i materialy 78 -i naukovoi konferentsii molodykh uchenykh, aspirantiv i studentiv «Naukovi zdobutky molodi - vyrishenniu problem kharchuvannia liudstva u XXI stolitti», Kyiv, NUFT, Vol. 1, 85-86.

22. Pivovarov, O. A., Mykolenko, S. Yu. (2011). Deryvatohrafichni doslidzhennia tista, pryhotovanoho z vykorystanniam plazmokhimichno aktyvovanykh vodnykh rozchyniv, Kharchova nauka i tekhnolohiia, 3 (16), 69-72.

23. Ablett, S., Lillford, P. (1991). Water in foods, Chemistry in Britain, 27, 1024-1026

\section{ACIDITY DYNAMICS OF HYDROLYZED SWEET CONDENSED MILK IN THE STORAGE PROCESS (p. 37-41)}

Yelena Kalinina, Oleksandr Kovalenko, Olga Kornilova

There is almost no market for low-lactose products in Ukraine, except infant formulas, that is why, about $10 \%$ of the population are limited to the consumption of dairy products. Recently, there are attempts in creating dairy products wherein the lactose is partially hydrolyzed by the $\beta$-galactosidase preparations. Creating low-lactose dairy products is of great social importance, the regulation of sugar profile of dairy products by the lactose fermentation is relevant. Herewith, lactose is split into monosaccharides glucose and galactose, the chemical composition of milk is changed, which enables saving sucrose when manufacturing sweet condensed milk, in the finished product organoleptic indicators are improved, excluded the possibility of lactose crystallization in sweet condensed milk during storage, the new products are designed for people intolerant to lactose and a wide range of people.

The studies of determining the quality of new products are given in the paper, the organoleptic and physico-chemical characteristics of hydrolyzed sweet condensed milk were defined for the first time: water activity, osmotic pressure, weight ratio of dry solids, titratable and active acidity in fresh products and during storage.

Keywords: low-lactose products, titratable acidity, active acidity, organoleptic characteristics, water activity.

\section{References}

1. Ostroukhov, D. (2008). Once again about lactose. Dairy industry, 2, 15.

2. Harju, M. (2005). Removal of lactose from milk. Dairy industry, 4, $52-54$.
3. Pashkovskaya, O. (2007). Nizkolaktoznyye and delactosed foods of company Valio. Processing of milk, November, 42.

4. Visser, R., Fergusson, W. (1988). Lactose and its chemical derivatives. Bull of IDF, 233, 33-44.

5. Mann, E. (1977). Utilization of lactose. Dairy industries international, Vol. 42, 2, 60-61.

6. Lamy, P. (1990). What is left of lactose intolerance Ann. Gastroent Hepatol, 26 (2), 61-65.

7. Shidlovskaya, B. (2004). Organoleptic properties of milk and dairy products. Colosus, 348

8. Chekulayeva, L. (2002). Technology of foods of canning of milk and suckling raw material. Delhi print, 245.

9. Radayeva, I. (2002). Ways of upgrading of sucklings can food. Suckling industry, 2, 43-46.

10. Galstyan, A., Petrov, A., Pavlova, V. (2002). The activity of the water in dairy products. Processing of milk, 7, 8-9.

11. Gudkov, A. (1978). Influence of water activity on the development of lactic acid bacteria. Dairy Industry, 10, 20-23

12. Scott, W. (1957). Water relation of Food Spoilage Microorganisms. Advances in Food Research, 7, 85-123.

13. Yeresko, G., Burtovaya, Z., Tsapyuk, E. (1987). Measurement of osmotic pressure of condensed milk products. Dairy industry, 5, 12-14

14. Golubev, L., Chekulaeva, L., Polyansky, K. (2001). Hranimosposobnost canned milk. DeLee print, 113.

15. Radaeva, I., Petrov, A. (2004). Vices canned and measures to prevent them. Dairy industry, 1, 37-40.

16. Polanski, K., Shuvayeva, G., Golubeva, L. (1995). Microbiological resistance milk, whole condensed with sugar. Dairy industry, 3, 12-13.

\section{IDENTIFICATION OF ENTEROBACTER SAKAZAKII IN RAW MILK FOR DRY INFANT FORMULA PRODUCTION (p. 42-47)}

Oleksandra Bergilevych, Yevhenuya Hryshyna, Victoria Kasianchuk

Microorganism E. sakazakii was first identified in Ukraine in general and in raw cow's milk in particular. Cultural, morphological and biochemical properties of 8 strains of this microorganism were studied, whereby one of the strains has been deposited with the National Collection. E. sakazakii was identified in raw milk in $22.3 \%$ of cases. Direct correlation between the total bacterial milk pollution and E. sakazakii identification was determined. Average E. sakazakii count in $1 \mathrm{ml}$ of raw milk, in which the total microbial count was up to $100.000 \mathrm{CFU} / \mathrm{ml}$, was from $3 \mathrm{CFU} / \mathrm{ml}$ to $10 \mathrm{CFU} / \mathrm{ml}$. In milk with high total bacterial pollution level $500.000 \mathrm{CFU} / \mathrm{ml}$, the $\mathrm{E}$. sakazakii count was on average $150 \mathrm{CFU} / \mathrm{ml}-200 \mathrm{CFU} / \mathrm{ml}$. Optimal raw milk storage conditions: $4{ }^{\circ} \mathrm{C}$ for $12-24$ hours, in which the E. sakazakii growth and development slows down were determined. Thermoresistivity level of E. sakazakii, which is $58{ }^{\circ} \mathrm{C}-60{ }^{\circ} \mathrm{C}$ was defined.

It was proved that the raw cow's milk can be a potential source of contamination of dry infant formulas by Enterobactersakazakii in case of failure of proper control over its obtaining, storage, transportation and processing and therefore pose a threat to children under the age of 12 months, who are fed by these formulas. It is recommended to pasteurize raw milk for producing dry infant formulas at a temperature no less than $70{ }^{\circ} \mathrm{C}$.

Keywords: enterobactersakazakii, dry infant formulas, total microbial count, raw milk.

\section{References}

1. Bowen, A. B., Braden, C. R. (2006). Invasive Enterobacter sakazakii disease in infants. Emerg. Infect. Dis., Vol. 12, 1185-1189.

2. Enterobacter sakazakii and other microrganisms in powdered infant formula: meeting report (2004). MRA Series 6. World Health Organization, 45.

3. The WTO Sanitary and Phytosanitary Measures. Agreement and SPS developments and activities around the world (2004). WTO, 45.

4. Fiore, A., Casale, M., Aureli, P. (2008). Enterobacter sakazakii: epidemiology, clinical presentation, prevention and control. Ann. Ist. Super. Sanità, Vol. 44, № 3, 275-280.

5. Norrakiah, A. S., Noorzatul, S. Md Z. (2009). Cronobacter (Enterobacter) sakazakii, Enterobacteriaceae and aerobic plate count in raw and pasteurized milk : 1st International Conference on Cronobacter. Lim Yen Yi, Poster 56. 
6. Kandhai, M. C., Heuvelink, A. E., Reij, M. W. (2010). A study into the occurrence of Cronobacter spp. in The Netherlands between 2001 and 2005. Food Control, Vol. 21, № 8, 1127-1136.

7. Buma, R., Sanada, H., Maeda, T. (1999). Isolation and characterization of pathogenic bacteria, including Escherichia coli O157:H7, from flies collected at a dairy farm field. Med. Entomol. Zool, Vol. 50, 313-321.

8. Iversen, C., Lehner, A., Mullane, N. (2007). The taxonomy of Enterobacter sakazakii: proposal of a new genus Cronobacter gen. nov. and description of Cronobacter sakazakii comb. nov. Cronobacter sakazakii subsp. sakazakii, comb. nov., Cronobacter sakazakii subsp. malonaticus subsp. nov., Cronobacter turicensis sp. nov., Cronobacter muytjensii sp. nov., Cronobacter dublinensis sp. nov. and Cronobacter genomospecies. BMC Evol Biol., 7, 64-67.

9. Drudy, D., O'Rourke, M., Murphy, M. (2006). Characterization of a collection of Enterobacter sakazakii isolates from environmental and food sources. Int. J. Food Microbiol, Vol. 110, № 2, 127-134.

10. Friedemann, M. (2007). Enterobacter sakazakii in food and beverages (other than infant formula and milk powder). Int. J.Food Microbiol, Vol. 116, 1-10.

11. Skladal, P., Mascini, M., Salvadori, C., Zannoni, G. (1993). Detection of bacterial contamination in sterile UHT milk as L-lactate biosensor. Enzyme Microb. Technol., Vol. 15, 508-512.

12. Muytjens, H. L., Kollee, L. A. (1990). Enterobacter sakazakii meningitis in neonates: causative role of formula. Pediatric Infectious Disease, Vol. 9, 372-385.

13. Salmon, S. A., Watts, J. L., Aarestrup, F. M. (1998). Minimum inhibitory concentrations for selected antimicrobial agents against organisms isolated from the mammary glands of dairy heifers in New Zealand and Denmark. J. Dairy Sci, Vol. 81, 570-578.

14. Berhilevych, A., Kasyanchuk, V., Garkavenko, T., Mezhynska, N. A. (2010). Methods of isolation and counting of bacteria Enterobacter (Cronobacter) sakazakii. Approved scientific methods Council of State Committee for Veterinary Medicine of Ukraine, 38.

15. ISO/TS 22964:2006. Milk and milk products (2006). Detection of Enterobacter sakazakii, 13.

16. Berhilevych, O. M., Kasyanchuk, V. V., Berhilevych, O. O., Mohutova, V. F. (01.01.2014). Patent of Ukraine for useful model № 86516. Method of fixing microorganisms of the fixator Trumpsa 4F: $1 \mathrm{G}$ to study their ultrastructure under scanning electron mikrosokpom. Applicant Sumy NAU, № 1, 5 seconds.

17. Berhilevych, O., Kasyanchuk, V., Berhilevych, O., Mohutova, V. (01.2014). Patent of Ukraine for useful model № 86516. Method of fixing microorganisms lock Trumpsa 4F: $1 \mathrm{G}$ to study their ultrastructure under scanning electron mikrosokpom. Applicant Sumy NAU, № 1, 5 seconds.

\section{STUDY OF THERMODYNAMICS OF COMPLEX FORMATION OF FLAVONOIDS OF STEVIA (STEVIA REBAUDIANA BERTONI) LEAVES (p. 47-50)}

Inga Kuznetchova

Scientists have studied the mechanisms of forming complexes between flavonoids of different plants and ions of iron and copper. Stevia is one of many plants, rich in biologically active substances and which is practically uninvestigated. In particular, the antioxidant effect of flavonoids of stevia leaves is not studied and there are no data on its thermodynamic properties, namely the possibility of natural flow of the complex formation process. There are no data on the possibility of forming the complex of flavonoids with aluminum ions.

Taking into account that the dried leaves of stevia (Stevia rebaudiana Berton) is a rich source of flavonoids, their antioxidant action was studied based on thermodynamic researches. It is determined that $65 \%$ of flavonoids of stevia leaves are involved in forming the complex with aluminum ions. The degree of complex formation of the flavonoids of the leaves of stevia, grown in different agro-climatic zones of Ukraine was calculated. The Gibbs energy of stevia flavonoids is $12,8-13,8$ that indicates the natural flow of the complex formation process. Stability constant of the formed complex is $250.6 \mathrm{l} / \mathrm{mol}$. It was determined that the stevia leaves are a rich source of flavonoids, which take active part in the complex formation and show antioxidant effect. The obtained research results have become the basis for the developed nomogram, which allows to speed up defining the complex formation degree depending on the content of flavonoids in stevia leaves.
Keywords: stevia leaves, flavonoids, complex formation degree, Gibbs energy, stability constant.

\section{References}

1. Schekatikhina, A. S., Kurchenko, V. P. (2011). Spektrofotometricheskaya description of kompleksov kvercetina, morina, taksifolina I silibina s ionami honeys (II). Trudy BGU, Vol. 6, Part 1 $76-85$

2. Piett, P.-G. (2000). Flavonoids as antioxidants. J. Nat. Prod, 63 , 1035-1042.

3. Zhezherya, V. A., Linnik, P. M. (2010). Content and forms of finding of aluminium is in water of the rivers of pool of Prip'yati. Sciences. labours of UKRNDGMI, Issue 259, 171-187.

4. Linnik, P. N., Zhezherya, V. A., Linnik, R. N. (2009). Nekotorykh osobennostyakh kompleksoobrazovaniya of $\mathrm{Al}$ (III) of s gumusovymi veschestvami. Metody of I ob'ekty khimicheskogo analiza, Vol. 4, № $1,73-84$.

5. Kuznetcova, I. V. (2013). Role of phenols and flavanoidiv in the estimation of quality of stevia (Stevia rebaudiana Bertoni). Newest technologies of growing of agricultural cultures: $\mathrm{Zb}$. sciences. pr. / for the editor of akad. NAAN Roika M.V, Issue 14, 146-150.

6. Burda, S., Oleszek, W. (2001). Antioxidant and antiradical activities of flavanoids. J. Agric. Food Chem, 49, 2774-2779.

7. Pedrielli, P., Pedulli, G. F., Skibsted, L. H. (2001). Antioxidant mechanism of flavonoids. Solvent effect on rate constant for chainbreaking reaction of quercetion and epicatechin in autoxidation of mathyl linoleate. J. Agric. Food Chem., 49, 3034-3040.

8. Pecal, A., Biesaga, M., Pyrzynska, K. (2010). Interaction of quercetin with copper ions: complexation, oxidation and reactivity towars radicals. Biometals, 330, 1173-1178.

9. Chernyakovskiy, E. M., Kurchenko, V. P., Kostyuk, V. A. Role of flavanoidov biologicheskikh reakcivakh by a transfer electrons. Available at: http://www.bio.bsu.by/proceedings/articles/2009-4-1-9-26.pdf.

10. Yakovishin, L. A., Rubinson, M. A., Grishkovec, V. I. (2012) Issledovanie of thermodynamics of molecular kompleksoobrazovaniya of saponinov ivy by a method spectrophotometers. Uchenye of message Tavricheskogo of national universiteta im. V. I. Vernadskogo. Seriya «Fiziko-matematicheskie sciences», Vol. 25 (64), № 1, $212-216$.

11. Tolstikova, T. G., Khvostov, M. V., Bryzgalov, A. O. (2009). The complexes of drugs with carbohydrate-containing plant metabolites as pharmacologically promising agents. Mini Rev. Med. Chem., Vol 9, № 11, 1317-1328.

12. Savita, S. M., Sheela, K., Sananda, S. (2004). Stevia rebaudiana-A functional component for food industry. J. Hum. Ecol, 15, 261-264.

13. Roik, M. V., Kuznecova, I. V, Rudakova, T. V. (12.10.12). Patent of Ukraine on an useful model, MPK9 S07 N 15/00, S07 N 17/00, G01 $\mathrm{N}$ a 21/00 Method of determination content of matters flavanoids complex. In-t of biopower cultures and sugar beets of NAAN. № u201211791.

14. Bulatov, M. I., Kalinkin, I. P. (1986). Prakticheskoe of rukovodstvo for to the fotometricheskim methods of analiza. Khimiya, 432.

15. Panhwar, Q. K., Mamon, Sh., Bhanger, M. I. (2010). Synthesis, characterization, sprctroscopic and antioxidant studies of $\mathrm{Cu}(\mathrm{II})$-morin complex. Journal of molecular structure, 967, 47-53.

\section{STUDY OF INFRARED SPECTRA OF EXTRACTS FROM ROSE HIP, SEA BUCKTHORN AND VIBURNUM (p. 51-55)}

Denis Mironov

The possibility of using a vortex layer of ferromagnetic particles for processing rose hip, sea buckthorn and viburnum in preparing them for the extraction process was considered. To study the influence of the turbulent layer of ferromagnetic particles on plant raw materials, the spectrophotometric method was chosen, as one of the most accessible and precise. The study aimed at investigating the influence of the turbulent laver of ferromagnetic particles on the qualitative indicators of plant extracts. The performed experiments allowed to confirm that extracts based on alcohol-water extractants do not differ from extracts based on water extractants. In extracts from fruits treated in the turbulent layer of ferromagnetic particles, the indicators of phenolics, sugar, biopolymers, organic acids were much higher than in the control samples. This allows to eliminate the stage of dealcoholizing plant extracts in the manufacture of soft 
drinks, to increase the quality indicators, and to develop new manufacturing technologies.

Keywords: IR - spectra, extracts, turbulent layer of ferromagnetic particles, dealcoholizing, soft drinks.

\section{References}

1. Mustafina, A. S. (1999). Development of technology of fruit extracts for use in the manufacture of dairy products. Kemerovo, 18.

2. Domarecki, V. A. (1990). Production of concentrates, extracts and beverages. Kiev, 250.

3. Burachevsky, I. I., Skripnikov, K. I. (1981). Modern methods of producing semi-finished distillery, 136.

4. Tutelian, V. A. (2005). Your health - in your hands, 6-8.

5. Babanin, A. A. (2001). The modern structure of power and its correction in order to prevent diseases century. Simferopol, 4-6.

6. Osipova, L. A., Kaprelyants, L. V., Burdo, O. G. (2007). Functional drinks. Odessa, 208.

7. Sorokopud, A. F., Mustafina, A. S. (1997). Study of physicochemical properties extracts chokeberry, 34-35.

8. Karpenko, P. O. (2000). Nutrition and health. In the book. Dietary supplements and organic products, $3-8$.

9. Kudryashov, A. A. (1999). Food XXI century and especially its creation, $48-50$.

10. Domaretsky, V. A., Pribilsky, V. L., Mikhailov, M. G. (2005). Technology extracts, concentrates and beverage products from vegetable raw materials. Vinnitsa, 408

11. Tcherevko, O. I., Poperechniy, A. M. (2002). Process and apparatus nutritive productions. Kharkov, 420.

\section{MATHEMATICAL SIMULATION OF THE ORGANIC DISPERSE MATERIAL MECHANICAL TREATMENT PROCESSES (p. 55-61)}

Evgen Shtefan, Dmitro Rindyuk, Sergey Kadomsky

The concept of presenting disperse masses in the form of twophase mixtures of porous or granular solid deformed structure with a liquid or gas is accepted. To describe the mechanical behavior of such materials, the notions of stresses, deformations, density and the rate of changing these parameters are used. Since these tensor and scalar properties have a local nature, mathematical operations of passage to the limit, when the space elements (volumes and surfaces) are contracted to the points (material) are proposed for their determining. This allowed to partially apply the traditional continuum models, in which points are identified with the particles of the medium (infinitesimal volume of material continuum), and they in turn are elementary carriers of the material properties.

Based on the accepted concepts, a new approach to creating mathematical models of mechanical treatment of food materials is proposed.

The basic provisions of this approach are:

- formulating boundary-value problems of the mechanics of disperse moisture-saturated food materials in the mode of elasto-viscoplastic deformation of the solid phase; tasks;

using computer projection-grid methods for solving the set

- modern computer technologies for effective use of software systems;

- developing and conducting experimental studies on determining the rheological properties of the solid phase of the material.

Using the developed model concepts on the structural-mechanical properties of disperse materials and corresponding digital models within the proposed information design technology will ensure performing a complex of design calculations when considering typical technological operations of processing raw disperse materials in the food and pharmaceutical industries.

Keywords: disperse materials, mathematical model, solid phase, processing, deformation, defining relationship.

\section{References}

1. Wang, Z., Sun, J., Xiaojun Liao, Chen, F., Zhao, G., Wu, J., Hu, X. (2007). Mathematical modeling on hot air drying of thin layer apple pomace. Food Research International, Vol. 40, Issue 1, 39-46.

2. Purlis, E., Salvadori, Viviana O. (2009). Modelling the browning of bread during baking. Food Research International, Vol. 42, Issue 7, 865-870.
3. Fois, S., Fadda, C., Tonelli, R., Sanna, M., Paolo, P., Roggio, T., Catzeddu, P. (2012). Rheology and microstructure of bimodal particulate dispersions: Model for foods containing fat droplets and starch granules. Food Research International, Vol. 48, Issue 2, 641-649.

4. Fischer, P., Erich, J. W. (2011). Rheology of food materials. Current Opinion in Colloid \& Interface Science, Vol. 16, Issue 1, 36-40.

5. Rindyuk, D. V., Lementar, S. Y. (2013). Information technology in designing high-performance equipment for biomass compacting Journal Food and Environment Safety of the Suceava University, Vol. XII, Issue 2, 115-122.

6. Valentas, C., Roshtein, E., Singh, R. (2004). Food engineering: a handbook with examples of calculations. Profession, 848.

7. Shtefan, E., Rindyuk, D. (2012). The study of structural and mechanical properties of plant dispersed materials. Journal of Vinnytsia National Agrarian University: Engineering, Vol. 10, Issue 1, 59-67.

8. Rindyuk, D. V., Lementar, S. Y. (2012). The method of determination of the optimal parameters of dispersed materials granulation through consolidation. Food and Environment Safety - Journal of Faculty of Food Engineering, Ştefan cel Mare University - Suceava, Vol. XI, Issue 2, 15-18.

9. Pai, P.-F, Hong, W. C. (2005). Forecasting regional electricity load based on recurrent support vector machines with genetic algorithms. Electric Power Systems Research, Vol. 74, 417-425.

10. Mohamed, Ibrahim O. (2009). Simultaneous estimation of therma conductivity and volumetric heat capacity for solid foods using sequential parameter estimation technique. Food Research International, Vol. 42, Issue 2, 231-236.

\section{INFLUENCE OF INCORPORATING HONEY, ROYAL JELLY AND POLLEN ON BIOTECHNOLOGICAL PROCESSES OF DAIRY DRINK (p. 62-65)}

Neonila Lomova, Olga Snezhko

The influence of adding bee honey, royal jelly and pollen on the incubation time, smell, taste and texture of dairy drink, obtained by the fermentation of starter cultures such as Lac. Lactis, Str. Thermophilus, Lbm. Acidophilum, Lbm. Bulgaricum, kefir, combined ( $1 / 3$ Str. Thermophilus, $1 / 3 \mathrm{Lbm}$. Acidophilum, 1/3 Lbm. Bulgaricum) was studied. The nature of influence of bee products on the yogurt microflora, including the third and sixth day of storage was studied.

Increasing the viability of yogurt microorganisms was proportional to the concentration of honey, pollen and royal jelly to a certain level. Further, the reverse process was observed.

Based on the preliminary results, a starter culture with which bee products are combined in the best way was defined. A possible dose of honey, royal jelly and bee pollen for the production of yoghurt with bee products was selected.

Keywords: yogurt, honey, royal jelly, pollen, biotechnology, starter preparation, organoleptic characteristics.

\section{References}

1. Stocker, A. (2005). Trace and Mineral Elements in Royal Jelly and Homeostatic Effects. Elements in Medicine and Biology, Vol. 19, 183-189.

2. Szczêsna, T. (2006). Protein Content and Amino Acid Composition of Bee-collected Pollen from Selected Botanical Origins. Journal of Apicultural Science, Vol. 50, №. 2, 81-90.

3. Mundo, M. A. (2004). Growth inhibition offoodborne pathogens and food spoilage organisms by select raw honeys. International Journal of Food Microbiology, Vol. 97, 1-8.

4. Attalla, K. M., Owayss, A. A., Mohanny, K. M. (2007). Antibacterial activities of bee venom, propolis and royal jelly produce by three honey bee, Apis mellifera L., hybrids reared in the same environmental conditions. Annals Of Agricultural Science, Moshtohor Journal, Vol. 45, 895-902.

5. Lomova, N. M., Slobodjanjuk, N. M. (25.02.10). Patent 49136 (UA), MPK A 23 S 9/00. Sposib virobnictva sirkovogo desertu. National universityt bioresursiv i prirodokoristuvannja Ukraine. № u200907157, № 8

6. Belinskaja, Ju. (2003). Istorija molochnoj kompanii «Galichina». Forb, № 6. Available at: http://forbes.ua/magazine/forbes/1353117istoriya-molochnoj-kompanii.

7. Ukrainec', A. I., Rashevs'ka, T. O., Pilipenko, N. V. (10.10.11) Patent 96219 (UA), MPK A 23 S 15/02. Sposib virobnictva vershkovogo masla z napovnjuvachem. National Universityt harchovih tehnologij. № a201005982, № 9 . 
8. El-Baz, A. M., Zommara, M. A. (2007). Characteristics of carbonated stirred yoghurt - bifidum milk fortified with honey and vitamin C. Egypt. J. Dairy Sci, 35, 45-56.

9. Abd El-Rahman, H. A., Salama, W. M. (2008). Preparation of yoghurt - like products with safflower as a substitution material. Egypt. J. Dairy Sci, 36, $39-44$.

10. Varga, L. (2006). Effect of acacia (Robinia pseudo-acacia L.) honey on the characteristicmicroflora of yoghurt during refrigerated storage. Inter. J.Food Microbiol, 108, 272-275.

11. Riazi, A., Zia, H. (2008). Growth and viability of yogurt starter organisms in honey-sweetened skimmed milk. African Journal of Biotechnology, Vol. 7 (12), 2055-2063.

12. Chick, H., Shin, H. S., Ustunol, Z. (2001). Growth and acid production by lacticacidbacteria and bifidobacteria grown in skim milk containing honey. J. Food Sci, 66, 478-481.

13. Ustunol, Z., Gandhi, H. (2001). Growth and viability of commercial Bifidobacterium spp. in honey-sweetened skim milk. J. Food Protec, 64, 1775-1779

14. Slačanac, V. (2011). Effect of honey addition on fermentation activity of Lactobacillus casei Lc-01 in cow's and goat's milk: A kinetic study. Acta Alimentaria, 40, 271-282.

15. Slačanac, V. (2012). Fermentation of honey-sweetened soymilk with Bifidobacterium lactis Bb-12 and Bifidobacterium longum Bb-46: fermentation activity of bifidobacteria and in vitro antagonistic effect against Listeria monocytogenes FSL N1-017. Czech J. Food Sci, $30,321-329$

\section{STARTER COMPOSITIONS FOR BABY CULTURED MILK PRODUCTS WITH HIGH LEVEL OF PROTEOLYTIC PROPERTIES (p. 66-71)}

Nataliya Tkachenko, Anastasiya Avershina, Yuliia Nazarenko, Yuliia Ukraintseva

The paper gives the results of selecting the adapted to milk bifidobacteria monocultures and lactic acid bacteria concentrates of direct application with high level of proteolytic properties for creating starter compositions of mixed lacto- and bifidobacteria cultures, intended for producing baby cultured milk products. It is shown that combining the use of mixed cultures of bifidobacteria and mesophilic lactic lactococci with high level of proteolytic proper- ties in the content of starter compositions, it is possible to produce cheese and fermented milk drinks for baby nutrition with hypoallergenic properties. The combination of bacterial concentrates of Lbc. Acidophilus monocultures of direct application with mixed cultures of bifidobacteria allows obtaining the compositions for producing fermented milk drinks for babies with reduced allergenic effects on babies' body. Starter compositions of monocultures/mixed cultures of bifidobacteria, bacterial concentrates of Lbc. Acidophilus monocultures of direct application and mesophilic lactic lactococci with high level of proteolytic properties can be used in biotechnology of producing protein pastes for babies with hypoallergenic properties.

Keywords: baby nutrition (food), cultured milk product, food

allergy, starter composition, proteolytic properties.

\section{References}

1. Malysham $\mathrm{v}$ Ukraine katastroficheski ne khvataet materinskogo moloka (2012). Available at: http://lekpravda.com/malyshamukrainekatastroficheski-ne-xvataet-materinskogo-moloka/

2. Rynok detskogo pitaniya v Ukraine. Available at: statuspress.com.ua.

3. Kuznetsov, V. V., Lipatova, N. N. (2005). Spravochnik tekhnologa molochnogo proizvodstva. Tekhnologiya detskikh molochnykh produktov. Sankt-Peterburg: GIORD, 525.

4. Ribeiro, A. C., Ribeiro, S. D. A. (2010). Specialty products made from goat milk. Small Ruminant Res, Vol. 9, 225-233.

5. Bottazzi, V. (2003). Milk, enzymes \& micro-organisms. Novara (Italy): MOFIN ALCE, 154.

6. Collins, M. D., Gibson, G. R. (1999). Probiotics, prebiotics and synbiotics: dietary approaches for the modulation of microbial ecology Am. J. Clin. Nutr, 5, 1052-1057.

7. Ericson, K. L., Hubbard, N. E. (2000). Probiotic immunomodulation in health and disease. J. Nutr., 2, 403-409.

8. Park, Y. W. (1994). Hypo-allergenic and therapeutic signif-icance of goat milk. Small Rum. Res,Vol. 14, 151-159.

9. Biavati, B., Bottazzi, V., Morelli, L. (2001). Probiotics and Bifidobacteria. Novara (Italy): MOFIN ALCE, 79.

10. Bannikova, L. A. (1987). Mikrobiologicheskie osnovi molochnogo proizvodstva: Spravochnik. Agropromizdat, 400

11. Didukh, N. A., Chaharovskyy, O. P., Lysohor, T. A. (2008). Zakvashuvalıni kompozytsiyi dlya vyrobnytstva molochnykh produktiv funktsionalnoho pryznachennya. Odesa: Vydavnytstvo «Polihraf», 236. 